Заячківська О. В. ${ }^{[1 ; 0 R C I D ~ I D: ~ 0000-0002-8792-9204], ~}$ к.е.н., доцент кафедри фінансів і економіки природокористування

${ }^{1}$ Національний університет водного господарства та природокористування, м. Рівне

\title{
ХАРАКТЕРИСТИКА НАУКОВИХ ПОГЛЯДІВ ЩОДО ПОНЯТТЯ «ЗОВНІШНЬОЕКОНОМІЧНА ДІЯЛЬНІСТЬ»
}

Стаття містить наукові погляди щодо поняття «зовнішньоекономічна діяльність». Розкрито та доповнено сутність поняття «зовнішньоекономічна діяльність». У висновках наведено авторське визначення даного поняття.

Ключові слова: фінанси; зовнішньоекономічна діяльність; Закон України «Про зовнішньоекономічну діяльність».

Постановка проблеми. В сучасних умовах роль і значення зовнішньоекономічної діяльності підвищується за рахунок глобалізації світового господарства та міжнародних економічних відносин. Це стосується як макро-, так і мікроекономічного рівня. Науковці та практики, які займаються питаннями удосконалення організації та управління зовнішньоекономічної діяльності підприємства, проводять постійний аналіз її сутності. У зв'язку з тим, що не існує однієї думки щодо поняття зовнішньоекономічної діяльності, на наш погляд, це є актуальною темою для обговорення.

Аналіз останніх досліджень i публікацій показав, що вивченням даного питання займалися багато вчених-економістів, зокрема А. П. Баскаков, Л. Головко, О. Гребельник, О. В. Валентієва, Л. Дідківська, Г. В. Дурицька, І. Манцурова, Л. Пісьмаченко, В. Покровська, Л. Швайк та ін. У їхніх працях проведена комплексна оцінка зовнішньоекономічної діяльності підприємств, здійснена характеристика особливостей іï ведення, здійснений аналіз статистичних індикаторів.

Виділення не вирішених раніше частин загальної проблеми. Разом з тим, на основі аналізу вищезазначених джерел, можна зробити висновок про багатовекторність, складність та неоднозначність у трактуванні поняття «зовнішньоекономічної діяльності». Саме тому метою статті $\epsilon$ систематизація наукових поглядів щодо даного питання та запропонувати авторське визначення. 
Виклад основного матеріалу. Для вирішення поставленого завдання та на основі вивчення наукової літератури, приведемо у вигляді таблиці погляди різних науковців (таблиця).

Таблиця

Наукові підходи до визначення поняття «зовнішньоекономічна діяльність» $[1 ; 2 ; 3 ; 4]$

\begin{tabular}{|c|c|c|}
\hline № & Автори & $\begin{array}{c}\text { Визначення поняття «зовнішньоекономічна } \\
\text { діяльність» }\end{array}$ \\
\hline 1 & 2 & 3 \\
\hline 1 & $\begin{array}{l}\text { Господарський } \\
\text { кодекс України }\end{array}$ & $\begin{array}{l}\text { визначає її як господарську діяльність, яка мусить } \\
\text { перетинати митний кордон України майном та (або) } \\
\text { робочою силою }\end{array}$ \\
\hline 2 & $\begin{array}{l}\text { Закон України «Про } \\
\text { зовнішньоекономічну } \\
\text { діяльність» }\end{array}$ & $\begin{array}{l}\text { діяльність суб'єктів господарської діяльності } \\
\text { України та іноземних суб'єктів господарської } \\
\text { діяльності, яка базується на взаємовідносинах між } \\
\text { ними та здійснюється як на території України, так і } \\
\text { за її межами }\end{array}$ \\
\hline 3 & Економічний словник & $\begin{array}{l}\text { визначає її через взаємозв'язок економічної } \\
\text { діяльності підприємства та зовнішньої торгівлі, } \\
\text { експорту, імпорту, іноземних кредитів та інвестицій, } \\
\text { здійснення з іншими країнами спільних проєктів }\end{array}$ \\
\hline 4 & $\begin{array}{l}\text { Д. Д. Гордієнко, } \\
\text { Ф. Ф. Бутинець, } \\
\text { А. Г. Загородній, } \\
\text { Г. Л. Вознюк }\end{array}$ & $\begin{array}{l}\text { здійснення як на території України, так і поза її } \\
\text { межами діяльності, яка виникає при взаєминах між } \\
\text { вітчизняними та чужоземними суб'єктами } \\
\text { господарювання }\end{array}$ \\
\hline 5 & В. Ю. Горчаков & $\begin{array}{l}\text { система, що забезпечує існування чотирьох } \\
\text { підсистем («Введення продукції на міжнародний } \\
\text { ринок», «Збільшення збуту нової продукції», } \\
\text { «Збереження конкурентної переваги», «Зниження } \\
\text { обсягу продажів») }\end{array}$ \\
\hline 6 & $\begin{array}{l}\text { В. М. Бурмістров, } \\
\text { К. В. Холодов }\end{array}$ & $\begin{array}{l}\text { область діяльності, яка пов'язана із виробництвом } \\
\text { товарів та послуг, що призначені для реалізації у } \\
\text { сфері міжнародного обміну завдячуючи } \\
\text { проведенню експортно-імпортних операцій, а } \\
\text { також проявляєтся у різних формах міжнародного } \\
\text { обміну у вигляді капіталу, трудовими ресурсами та } \\
\text { об'єктами інтелектуальної власності }\end{array}$ \\
\hline 7 & Г.М.Дроздова & $\begin{array}{l}\text { при виході підприємства на зовнішній ринок } \\
\text { зовнішньоекономічна діяльність повинна містити } \\
\text { виробничо-господарські, організаційно-економічні } \\
\text { та оперативно-комерційні функції підприємства, } \\
\text { для його участі в зовнішньоекономічних операціях }\end{array}$ \\
\hline 8 & А. В. Ковалевська & $\begin{array}{l}\text { міжнародний обмін матеріальними цінностями та } \\
\text { послугами, який пов'язаний } 3 \text { теоретичними та } \\
\text { практичними знаннями, що взаємодіють } 3 \\
\text { організацією та технікою проведення міжнародних } \\
\text { комерційних операцій }\end{array}$ \\
\hline
\end{tabular}


продовження таблиці

\begin{tabular}{|c|l|l|}
\hline 1 & \multicolumn{1}{|c|}{2} & \multicolumn{1}{|c|}{3} \\
\hline 9 & $\begin{array}{l}\text { І. М. Паски, } \\
\text { А. О. Фатенок-Ткачук }\end{array}$ & $\begin{array}{l}\text { це система зі своїми специфічними організаційно- } \\
\text { економічними та правовими механізмами } \\
\text { функціонування, а також як складова єдиного } \\
\text { національного комплексу }\end{array}$ \\
\hline 10 & В. В. Покровська & $\begin{array}{l}\text { сукупність виробничо-господарських, } \\
\text { організаційно-економічних та оперативно- } \\
\text { комерційних функцій експортно-орієнтованих } \\
\text { підприємств з урахуванням обраної економічної } \\
\text { стратегії, форм та методів роботи на ринку } \\
\text { іноземного партнера }\end{array}$ \\
\hline 11 & Л. О. Чернишова & $\begin{array}{l}\text { зв'язок міжнародної виробничої та науково- } \\
\text { технічної кооперації, експорту та імпорту } \\
\text { продукції, виходу підприємства на зовнішній } \\
\text { ринокзі сферою його господарськоїдіяльності }\end{array}$ \\
\hline
\end{tabular}

Наведені в таблиці інтерпретації підтверджують той факт, що зовнішньоекономічна діяльність $€$ частиною загальної діяльності підприємства, але вона також має характерну особливість, суть якої полягає в тому, що вона здійснюється на іншому, міжнародному рівні, який виявляється у відносинах з контрагентами з інших країн. Слід зауважити, що агрегована економічна категорія, якою $\epsilon$ зовнішньоекономічна діяльність, класифікується за типами, формами та видами (рис. 1).

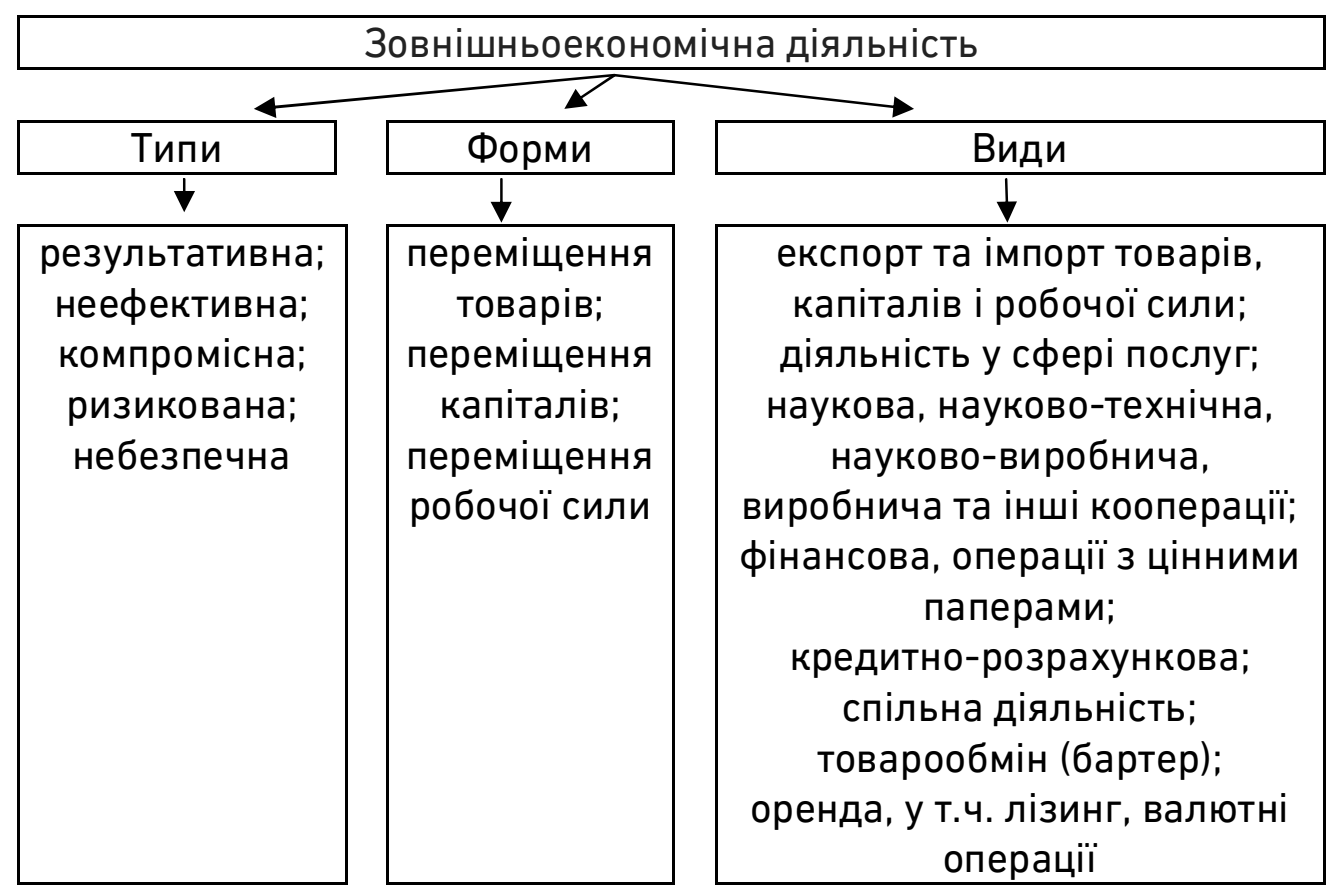

Рис. 1. Класифікаційні ознаки дефініції «зовнішньоекономічної діяльності» $[5$, C. $184 ; 6$, C. 74$]$ 
Аналізуючи наукові джерела, можна сказати, що економічна сутність зовнішньоекономічної діяльності проявляється в тому, що вона є: важливим і потужним фактором економічного зростання і розвитку кожної країни; спосіб включення економіки кожної країни до світової економіки, а отже, і до процесів міжнародного поділу праці та міжнародного співробітництва, що особливо актуально в контексті зростаючої глобалізації. Слід наголосити, що зовнішньоекономічна діяльність має суб'єкти макроекономічного (рис. 2) та мікроекономічного рівня (рис. 3).

\section{Суб'єкти макроекономічного рівня ЗЕД}

Україна як держава в особі її
повноважених органів в межах
їх компетенції

Недержавні органи управління економікою, до яких належать: товарні, валютні, фондові біржі, асоціації та спілки

Рис. 2. Суб'єкти зовнішньоекономічної діяльності України макроекономічного рівня [5, С. 184]

\begin{tabular}{l} 
Суб'єкти мікроекономічного рівня ЗЕД \\
\multicolumn{1}{|c|}{} \\
фізичні особи \\
юридичні особи \\
об'єднання фізичних, юридичних, фізичних і юридичних осіб \\
структурні одиниці суб'єктів господарської діяльності іноземних \\
суб'єктів господарської діяльності \\
спільні підприємства \\
інші суб'єкти господарської діяльності
\end{tabular}

Рис. 3. Суб'єкти зовнішньоекономічної діяльності України мікроекономічного рівня [5, С. 185]

Отже, ми бачимо 3 рис. 2 та 3 , що зовнішньоекономічна діяльність має суттєву специфіку, що пов'язана із функціонуванням та взаємодією суб'єктів на міжнародному рівні.

Вона $є$ самостійною діяльністю суб'єкта господарювання, яка $є$, з одного боку, структурним елементом господарської діяльності даного суб'єкта, а з другої - такою частиною його діяльності, яка проводиться на іншому, міжнародному рівні, яка вимагає зв'язку 3 господарськими суб'єктами інших країн [7]. 
Серія «Економічні науки»

Випуск 3(91) 2020 р.

Висновки і пропозиції. Провівши аналіз та врахувавши наукові підходи до визначення сутності «зовнішньоекономічна діяльність» можна стверджувати, що це частина загальної діяльності підприємства, яка виникає внаслідок взаємодії суб'єктів господарювання України та іноземних партнерів, задля ефективного здійснення міжнародної діяльності між ними.

1. Болотова О.С., Чмут А. В. Сутність дефініції «зовнішньоекономічна діяльність підприємства». Актуальні питання економічного розвитку в сучасних умовах : V Всеукраїнська науково-практична конференція (26-27 березня 2020 року). Херсон, 2020. С. 13-16. 2. Погребняк А. Ю., Хоменко Т. Ю. Еволюція наукових поглядів на сутність поняття «зовнішньоекономічна діяльність». Сучасні проблеми економіки і підприємництво. 2016. Вип. 18. С. 48-55. 3. Шталь Т. В., Зосимова Ж. С. Наукові підходи до визначення поняття зовнішньоекономічної діяльності підприємства. Вісник ОНУ ім. І. І. Мечникова. 2013. Вип. 1/1. Т. 18. С. 134-136. 4. Про зовнішньо-економічну діяльність : Закон України від 16.04.1991 № 959-XII, із змінами. URL: https://zakon.rada.gov.ua/laws/show/959-12\#Text (дата звернення: 16.09.2020). 5. Новіков О. Є., Садрідінов Т.Ш. Систематизація наукових поглядів щодо визначення сутності терміна «зовнішньоекономічна діяльність». Вісник Хмельницького національного університету. 2014. № 2. Т. 2. С. 183-186. 6. Пісьмаченко Л. М. Державне управління зовнішньоторгівельною діяльністю в Україні: регулювання та контроль : монографія. Донецьк : ТОВ «Юго-Восток, Лтд», 2008. 366 с. 7. Дроздова Г.М. Менеджмент зовнішньоекономічної діяльності підприємства : навчальний посібник для вузів. Київ : ЦУЛ, 2005. 172 с.

\section{REFERENCES:}

1. Bolotova 0. S., Chmut A. V. Sutnist definitsii «zovnishnoekonomichna diialnist pidpryiemstva». Aktualni pytannia ekonomichnoho rozvytku $v$ suchasnykh umovakh : $\mathrm{V}$ Vseukrainska naukovo-praktychna konferentsiia (26-27 bereznia 2020 roku). Kherson, 2020. S. 13-16. 2. Pohrebniak A. Yu., Khomenko T. Yu. Evoliutsiia naukovykh pohliadiv na sutnist poniattia «zovnishnoekonomichna diialnist». Suchasni problemy ekonomiky $i$ pidpryiemnytstvo. 2016. Vyp. 18. S. 48-55. 3. Shtal T. V., Zosymova Zh. S. Naukovi pidkhody do vyznachennia poniattia zovnishnoekonomichnoi diialnosti pidpryiemstva. Visnyk ONU im. I. I. Mechnykova. 2013. Vyp. 1/1. T. 18. S. 134-136. 4. Pro zovnishnoekonomichnu diialnist : Zakon Ukrainy vid 16.04.1991 № 959-XII, iz zminamy. URL: https://zakon.rada.gov.ua/laws/show/959-12\#Text (data zvernennia: 16.09.2020). 5. Novikov 0. Ye., Sadridinov T. Sh. Systematyzatsiia naukovykh pohliadiv shchodo vyznachennia sutnosti termina «zovnishnoekonomichna diialnist». Visnyk Khmelnytskoho natsionalnoho universytetu. 2014. № 2. T. 2. S. 183-186. 6. Pismachenko L. M. Derzhavne upravlinnia zovnishnotorhivelnoiu diialnistiu $v$ Ukraini: rehuliuvannia ta kontrol : monohrafiia. Donetsk : TOV «Yuho-Vostok, Ltd», 2008. 366 s. 7. Drozdova H. M. Menedzhment zovnishnoekonomichnoi diialnosti pidpryiemstva : navchalnyi posibnyk dlia vuziv. Kyiv : TsUL, 2005. $172 \mathrm{~s}$. 
Zaiachkivska O. V. [1; ORCID ID: 0000-0002-8792-9204], Candidate of Economics (Ph.D.), Associate Professor of the Department of Finance and Environmental Economics

${ }^{1}$ National University of Water and Environmental Engineering, Rivne

\section{CHARACTERISTICS OF SCIENTIFIC VIEWS ON THE CONCEPT OF «FOREIGN ECONOMIC ACTIVITY»}

The economic transformations taking place in Ukraine are aimed at the gradual integration of Ukrainian enterprises into the system of international economic relations, on the one hand, and the involvement of foreign entrepreneurs in Ukraine - on the other. The importance of such ties in the development of countries, including Ukraine, is constantly growing. The historical development of a number of countries confirms the positive impact and benefits of expanding the participation of each of them in the international division of labor and in various forms of international relations. It is obvious that the foreign economic activity of each country is an important condition for its economic growth. This is especially true in modern conditions, when the processes of international economic integration, transnationalization, international division of labor, globalization of the world economy are gaining intensive development. Foreign economic activity promotes the development of promising areas of export potential; It is at the expense of foreign economic activity that our country solves the problem of shortage of energy, the latest machinery and equipment, technology, and some consumer goods. The article contains scientific views on the concept of «foreign economic activity». The essence of the concept of «foreign economic activity» is revealed and supplemented. The conclusions provide the author's definition of this concept. Given all the above, we can conclude that foreign economic activity is part of the overall activities of the enterprise, which arises from the interaction of economic entities of Ukraine and foreign partners, for the effective implementation of international activities between them. It is an independent activity of an economic entity, which is, on the one hand, an integral part of the economic activity of the entity, and on the other - such part of its activities, which is carried out at another, international level, which requires communication with economic entities objects of other countries.

Keywords: finance; foreign economic activity; Law of Ukraine «On foreign economic activity». 
Заячкивская О. В. ${ }^{[1 ; 0 R C I D ~ I D: ~ 0000-0002-8792-9204], ~}$ к.э.н., доцент кафедры финансов и экономики природопользования

${ }^{1}$ Национальный университет водного хозяйства и природопользования, г. Ровно

\section{ХАРАКТЕРИСТИКА НАУЧНЫХ ТОЧЕК ЗРЕНИЯ ОТНОСИТЕЛЬНО ПОНЯТИЯ «ВНЕШНЕЭКОНОМИЧЕСКАЯ ДЕЯТЕЛЬНОСТЬ»}

Экономические преобразования, которые происходят в Украине, имеют целью постепенную интеграцию украинских предприятий в систему международных экономических связей, с одной стороны, и привлечение иностранных предпринимателей к деятельности в Украине - с другой. Значимость таких связей в развитии стран, в том числе и Украины, постоянно растет. Историческое развитие ряда стран подтверждает положительное влияние и выгодность расширения участия каждой из них в международном разделении труда и в различных формах международных связей. Очевиден тот факт, что внешнеэкономическая деятельность каждой страны является важным условием ее экономического роста. Особенно это актуально в современных условиях, когда приобретают интенсивного развития процессы международной экономической интеграции, транснационализации, международного разделения труда, глобализации мирового хозяйства. Внешнеэкономическая деятельность способствует развитию перспективных направлений экспортного потенциала; именно за счет внешнеэкономической деятельности наша страна решает проблему нехватки энергоносителей, новейших машин и оборудования, технологий, некоторых товаров народного потребления. Статья содержит научные взгляды на понятие «внешнеэкономическая деятельность». Раскрыта и дополнена сущность понятия «внешнеэкономическая деятельность». В выводах приведено авторское определение данного понятия. Учитывая все выше сказанное, можно сделать вывод, что внешнеэкономическая деятельность - это часть общей деятельности предприятия, которая возникает вследствие взаимодействия субъектов хозяйствования Украины и иностранных партнеров, для эффективного осуществления международной деятельности между ними. Она является самостоятельной деятельностью предприятия, которая является, с одной стороны, составной частью хозяйственной деятельности данного субъекта, а с другой - такой частью его деятельности, осуществляемой на другом, международном уровне, которая требует связи с хозяйственными субъектами других стран.

Ключевые слова: финансы; внешнеэкономическая деятельность; Закон Украины «О внешнеэкономической деятельности».

Стаття надійшла до редакції 17.09.2020 p. 